\title{
PENGARUH PENGGUNAAN ALAT PERMAINAN EDUKATIF DI LUAR KELAS TERHADAP PERILAKU PROSOSIAL ANAK USIA DINI
}

\author{
Ridha Marissa El-Seira, Badru Zaman ${ }^{1}$ dan Rita Mariyana ${ }^{2}$ \\ Program Studi Pendidikan Guru Pendidikan Anak Usia Dini, Departemen Pedagogik, \\ Fakultas Ilmu Pendidikan, Universitas Pendidikan Indonesia \\ ridhamarissa@gmail.com
}

\begin{abstract}
Abstrak
Penelitian ini dilatarbelakangi oleh kurangnya perilaku prososial anak ketika berinteraksi dengan teman-temannya. Penelitian ini bertujuan untuk mengetahui bagaimana pengaruh pengunaan alat permainan edukatif di luar kelas terhadap perilaku prososial anak usia dini. Metode yang digunakan pada penelitian ini adalah metode pre eksperimen dengan desain one-group pretest-posttest design. Populasi pada penelitian ini adalah seluruh anak kelompok B di Raudhatul Athfal Al-Hikmah Bandung tahun ajaran 2017-2018 dengan jumlah populasi 15 anak. Adapun sampel pada penelitian ini berjumlah 15 anak yang ditentukan dengan teknik sampling jenuh. Instrumen yang digunakan pada penelitian ini merupakan daftar cek observasi yang kemudian dianalisis menggunakan statistika inferensial. Hasil dari penelitian ini menunjukkan ketika hipotesis diuji pada $\alpha=0,05$ dengan menggunakan uji Wilcoxon Match Pairs Test, didapatkan hasil $\mathrm{p}=0,001$ yang berarti alat permainan edukatif di luar kelas mempunyai pengaruh yang signifikan dalam meningkatkan perilaku prososial anak. Peningkatan tersebut tidak terlepas dari faktor alat permainan edukatif di luar kelas, karakteristik anak dan waktu pelaksanaan penelitian. Berdasarkan hasil penelitian tersebut, hendaknya guru dapat memperhatikan penggunaan alat permainan edukatif di luar kelas untuk meningkatkan perilaku prososial anak usia dini.
\end{abstract}

\section{Kata kunci : Perilaku Prososial, Alat Permainan Edukatif di Luar Kelas}

\begin{abstract}
This research is motivated by the lack of prosocial behavior of children when interacting with his friends. This study aims to find out how the influence of the use of educational games outside the classroom against the behavior of prosocial young children. The method used in this research is pre experimental method with one-group pretest-posttest design. The population in this study is all the children of group B in Raudhatul Athfal Al-Hikmah Bandung academic year 2017-2018 with population of 15 children. The sample in this study amounted to 15 children determined by saturated sampling technique. The instrument used in this study is a check list of observations which are then analyzed using inferential statistics. The results of this study indicate that when hypotheses were tested at $\alpha=0.05$ using Wilcoxon Match Pairs Test, $\mathrm{p}=0,001$ means that educational game tools outside the classroom had a significant influence in improving the child's prosocial behavior. The increase is inseparable from the educational game tool factor outside the classroom, the characteristics of the child and the time of the research. Based on the results of this study, researchers recommended teachers to regard to the use of outdoor educational play equipment to increase the child's prosocial behavior.
\end{abstract}

Keywords : Prososial Behavior, Outdoor Educational Play Equipment

\footnotetext{
${ }^{1}$ Penulis Penanggung Jawab

${ }^{2}$ Penulis Penanggung Jawab
} 


\section{PENDAHULUAN}

Anak dilahirkan dengan potensi yang beragam yaitu moral agama, fisik motorik, kognitif, bahasa, sosial-emosional, dan seni yang pada masa yang akan datang akan berkembang seiring dengan berjalannya waktu. Potensi-potensi tersebut dapat dioptimalisasi melalui jenjang Pendidikan Anak Usia Dini (PAUD). PAUD merupakan lingkungan sekolah bagi anak usia dini sebelum memasuki jenjang pendidikan dasar. Pada jenjang ini pendampingan dalam pencapaian perkembangan pada anak diperlukan untuk mengoptimalkan seluruh aspek perkembangan anak melalui pemberian stimulasi dari pihak sekolah.

Salah satu potensi yang sangat penting untuk distimulasi adalah aspek perkembangan sosial-emosional. Aspek tersebut merupakan penghubung aspekaspek lainnya dalam perkembangan seseorang, sebagaimana yang dimaksudkan dalam Teori Erikson (dalam Supratiknya, 1993, hlm. 138) bahwa tahap perkembangan individu selama siklus hidupnya, dibentuk oleh pengaruh sosial yang berinteraksi dengan individu yang menjadi matang secara fisik dan psikologis. Seorang anak akan mendapat banyak pengalaman untuk membangun aspek perkembangan sosial-emosionalnya melalui interaksi dengan lingkungan tempat mereka berada secara utuh.

Interaksi dengan lingkungan sosial pada anak biasanya ditunjukkan dengan sikap saling berbagi, menghargai orang lain, mampu bekerja sama, dan saling tolong menolong. Sikap-sikap tersebut merupakan bentuk dari perilaku prososial sebagai bagian dari aspek perkembangan sosial-emosional. Eisenberg dan Mussen (1989, hlm. 3) mengatakan bahwa perilaku prososial mengacu pada tindakan sukarela untuk membantu individu atau kelompok individu lain yang dilakukan secara sukarela dan bukan di bawah paksaan. Seseorang yang berperilaku prososial dengan demikian tidak melakukan perilaku menolong secara terpaksa, tetapi dilakukan atas dasar motivasi dirinya sendiri.

Perilaku prososial dalam kehidupan sehari-hari pada anak usia dini idealnya mencakup perilaku empati, dimana anakanak mengekspresikan kasih sayang dengan menghibur seseorang yang sedang kesusahan atau dengan mengungkapkan perasaan anak lainnya selama konflik antar individu; kemurahan hati, dimana anakanak berbagi atau memberikan miliknya kepada seseorang; kerja sama, dimana anak-anak bergiliran secara sukarela atau memenuhi permintaan dengan riang; dan kepedulian, dimana anak-anak membantu seseorang menyelesaikan tugas atau membantu seseorang yang membutuhkan (Beaty, 2013, hlm 168). Sikap-sikap tersebut perlu dimiliki oleh seorang anak agar lingkungan sosial mereka dapat menerima diri mereka dengan baik sampai kelak mereka dewasa, sehingga sangat penting untuk diberi stimulasi sedini mungkin.

Stimulasi pengembangan perilaku prososial dapat diberikan pada anak melalui guru sebagai contoh bagaimana menunjukkan kepedulian kepada orangorang yang sedang kesusahan, mencontohkan perilaku berbagi satu sama lain, menjadi teladan dalam bersikap dermawan kepada orang lain, serta mencontohkan perilaku yang menunjukkan kerja sama pada anak. Selain peran guru, penggunaan media dan alat permainan seperti pembacaan buku cerita, menggambar, penyediaan cermin bagi anak dan mainan atau kegiatan khusus untuk mengajarkan anak mengambil giliran dapat membantu anak untuk memunculkan perilaku prososial mereka (Beaty, 2013, hlm. 170-194). Hal-hal tersebut dilakukan guna menstimulasi perilaku prososial anak, sehingga anak dapat mengerti bagaimana berinteraksi, menolong teman, berbagi, juga memahami diri sendiri dan orang lain ketika anak berinteraksi dengan lingkungan sosial mereka. 
Berbagai stimulasi sebenarnya dapat diterapkan guna mengembangkan perilaku prososial pada anak usia dini. Pada kenyataannya, saat ini perilaku prososial pada anak usia dini masih terbilang rendah. Hal tersebut terlihat pada sebuah penelitian yang dilakukan di Belanda oleh Wildeboer (2017) mengemukakan bahwa beberapa anak menunjukkan perilaku menolong, namun kecenderungan antisosial seperti bullying juga kerap ditemukan pada anak usia dini. Beberapa perilaku antisosial menjadikan anak sulit untuk mengembangkan diri dan terlibat pada situasi sosial yang baik (Wildeboer, 2017). Keadaan yang serupa juga terlihat di wilayah Indonesia, anak kurang berempati pada teman sebayanya, belum dapat berbagi, emosi mudah meledak, kurang memiliki sikap toleran,anak lebih senang bermain sendiri, dan sulit untuk meminta maaf (Debora, 2017).

Adapun hasil observasi anak kelas B

di Raudhatul Athfal Al-Hikmah Kota Bandung pada hari Rabu, tanggal 19 Juli 2017, diketahui bahwa kemampuan anak dalam berperilaku prososial masih cukup rendah. Anak masih perlu di dorong untuk meminta maaf ketika melakukan kesalahan, anak belum berinisiatif menawarkan bantuan kepada temannya yang sedang kesusahan, beberapa anak belum bisa menunggu giliran ketika menginginkan suatu permainan yang sama dengan temannya. Permasalahanpermasalahan anak yang tidak menunjukkan perilaku prososial ini, jika dibiarkan kemudian akan berdampak pada perilaku di masa yang akan datang, dengan lemahnya empati dan tidak adanya rasa saling mengasihi satu-sama lain.

Permasalahan-permasalahan di atas sebenarnya dapat diantisipasi melalui stimulasi yang tepat untuk mengoptimalkan perilaku prososial anak. Salah satu penelitian dari Wooley, H. dan Lowe, A (2013), mengemukakan bahwa interaksi sosial seperti bekerja dalam kelompok, berbagi, bekerja sama, dan menyelesaikan masalah dapat distimulasi dengan menyediakan alat permainan di luar kelas yang dapat memungkinkan anak untuk bergerak bebas dan saling berinteraksi dengan teman-teman lainnya. Adapun penelitian lainnya menunjukkan bahwa perilaku prososial anak pada beberapa sekolah lebih efektif ketika anak bermain di area terbuka dengan dilengkapi alat permainan yang nyaman bagi mereka sehingga anak akan lebih terbiasa berperilaku prososial (Mayfield, dkk, 2017). Kedua penelitian tersebut samasama mengungkapkan bagaimana area luar kelas dapat menstimulasi perilaku prososial pada anak usia dini.

Beberapa hasil penelitian yang sebelumnya telah dipaparkan, terlihat bahwa perilaku prososial pada anak usia dini dapat lebih terstimulasi ketika anak bermain di luar kelas dengan menggunakan alat permainan. Melalui bermain di lingkungan terbuka, anak lebih cepat untuk mengenali lingkungan sosial terdekatnya. Semakin terbuka ruang bagi anak untuk bermain, semakin besar pula kesempatan mereka untuk mengembangkan perilaku prososial mereka.

Seiring dengan masih terbatasnya penggunaan alat permainan edukatif untuk mengembangkan perilaku prososial pada anak, salah satu alternatif yang dapat digunakan, yaitu melalui penggunaan alat permainan edukatif di luar kelas. Alat Permainan Edukatif (APE) merupakan segala sesuatu yang dapat digunakan sebagai sarana atau alat permainan yang mengandung nilai pendidikan dan dapat mengembangkan seluruh aspek kemampuan anak, baik yang berasal dari lingkungan sekitar (alam) maupun yang sudah dibuat (dibeli) (Abidin, 2009, hlm. 59). Keberadaan berbagai alat permainan edukatif baik yang berasal dari alam maupun yang sudah dibuat, diharapkan mampu meningkaan perilaku prososal anak pada interaksi sosial yang lebih kompleks.

Penggunaan alat permainan edukatif yang beragam di lembaga pendidikan anak 
usia dini merupakan suatu komponen yang sangat penting untuk meningkaan perilaku prososial pada anak. Ketika anak melakukan berbagai permainan dengan berbagai media dan guru melakukan interaksi, disamping memberikan penguatan untuk meningkaan kemampuan berpikir anak (Sumartini, 2012, hlm. 23). Hal ini merupakan pemberian stimulasi yang sangat berharga bagi anak usia prasekolah untuk dapat mengembangkan pemahaman mereka terhadap perilaku prososial. Adapun alat permainan edukatif yang beragam lebih banyak ditemukan di area luar kelas, dibandingkan dengan area dalam kelas, seperti ayunan, mangkuk putar, papan seluncur, terowongan, balok keseimbangan, jaring, dan area bermain air yang dapat dimanfaaan anak untuk memunculkan perilaku prososial. Mariyana (2010, hlm. 104-105) mengatakan, anak menjadi lebih mudah membicarakan perasaan diri mereka saat duduk di ayunan atau pun area permainan lainnya di luar ruangan. Alat permainan edukatif pada area luar kelas dapat mengajarkan anak untuk saling berempati dan saling menolong, dibandingkan dengan saat mereka bermain di dalam kelas yang tidak terlalu banyak interaksi dalam bekerja sama dan saling tolong menolong.

Berdasarkan latar belakang tersebut, maka rumusan masalah dalam penelitian ini ialah sebagai berikut:

1. Bagaimana profil perilaku prososial anak sebelum penggunaan alat permainan edukatif di luar kelas?

2. Bagaimana profil perilaku prososial anak sesudah penggunaan alat permainan edukatif di luar kelas?

3. Apakah terdapat perbedaan yang signifikan pada perilaku prososial anak sebelum dan sesudah penggunaan alat permainan edukatif di luar?

Adapun tujuan dari penelitian ini ialah sebagai berikut:

1. Untuk mengetahui profil perilaku prososial anak sebelum penggunaan alat permainan edukatif di luar kelas.
2. Untuk mengetahui profil perilaku prososial anak sesudah penggunaan alat permainan edukatif di luar kelas.

3. Untuk mengetahui perbedaan pada perilaku prososial anak sebelum dan sesudah penggunaan alat permainan edukatif di luar kelas.

\section{METODE}

1. Jenis Penelitian

Penelitian ini menggunakan penelitian kuantitatif dengan menggunakan metode pre eksperimen. Metode eksperimen pada penelitian ini kemudian menggunakan desain penelitian one group pretest posttest design. Desain ini bertujuan untuk mengetahui kemampuan perilaku sebelum dan sesudah pelaksanaan penelitian pada subjek yang sama.

Tabel 3.1

Desain Penelitian

\begin{tabular}{|c|c|c|c|}
\hline Kelas & $\begin{array}{c}\text { Pre } \\
\text { test }\end{array}$ & Perlakuan & $\begin{array}{c}\text { Post } \\
\text { test }\end{array}$ \\
\hline Eksperimen & $\mathrm{O} 1$ & $\mathrm{X}$ & $\mathrm{O} 2$ \\
\hline
\end{tabular}

2. Subjek Penelitian

Subjek penelitian ini adalah anak kelompok B sebanyak 15 orang anak yang terdiri dari 8 orang anak laki-laki dan 7 orang anak perempuan di Raudhatul Athfal Al-Hikmah Kota Bandung yang berlokasi di Jalan Kaum Kidul, Kecamatan Cinambo, Kota Bandung.

Teknik sampling yang digunakan pada penelitian ini menggunakan sampling jenuh. Hal ini sering dilakukan bila jumlah populasi relatif kecil, kurang dari 30 orang, atau penelitian yang ingin membuat generalisasi dengan kesalahan yang sangat kecil (Sugiyono, 2011, hlm. 126). Penggunaan teknik ini dipilih berdasarkan jumlah populasi penelitian yang sedikit, sehingga semua anggotanya dijadikan sampel. 
3. Teknik Pengumpulan Data

Teknik pengumpulan data pada penelitian ini menggunakan observasi dan dokumentasi.

a. Observasi

Observasi merupakan pengamatan terhadap pola perilaku seseorang. Penggunaan teknik observasi penting untuk dilakukan pada penelitian yang berhubungan dengan perilaku seseorang. Berdasarkan cara pengamatan yang dilakukan, teknik observasi yang dilakukan pada penelitian ini menggunakan observasi terstruktur. Sugiyono (2016, hlm. 215) mengemukakan bahwa, observasi terstruktur dirancang secara sistematis, tentang apa yang akan diamati, kapan, dan di mana tempatnya. Observasi terstruktur digunakan ketika peneliti tahu pasti tentang variabel yang akan diamati dengan mengamati menggunakan instrumen penelitian yang telah teruji validitas dan reliabilitasnya.

b. Dokumentasi

Dokumentasi merupakan pelengkap dari pengambilan data observasi dalam penelitian ini. Dokumentasi dalam penelitian ini menggunakan dokumentasi berbentuk gambar atau foto selama penelitian. Penggunaan dokumentasi sangat mendukung pengambilan data. Hal tersebut karena dokumentasi dalam bentuk apapun yang merekam kejadian yang telah berlalu dapat jadi pelengkap data jika data dalam penelitian dirasa belum maksimal.

\section{Teknik Analisis Data}

Pengujian pengaruh penggunaan alat permainan edukatif di luar kelas terhadap perilaku prososial anak usia dini dilakukan dengan uji Wilcoxon Match Pairs Test.

Adapun formulasi hipotesis yang diuji adalah:
$\mathrm{H}_{0}$ : Tidak terdapat perbedaan yang signifikan pada perilaku prososial anak sebelum dan sesudah penggunaan alat permainan edukatif di luar kelas pada Raudhatul Athfal Al-Hikmah Kota Bandung.

$\mathrm{H}_{\mathrm{a}}$ : Terdapat perbedaan yang signifikan pada perilaku prososial anak sebelum dan sesudah penggunaan alat permainan edukatif di luar kelas pada Raudhatul Athfal AlHikmah Kota Bandung.

Pengambilan keputusan dilakukan dengan menakan diuji pada $\alpha=0,05$ atau pada taraf kesalahan 5\%. Dasar pengambilan kesimpulan tersebut sesuai dengan ketentuan sebagai berikut:

- Jika $P>0,05$ maka $\mathrm{H}_{\mathrm{O}}$ diterima

- Jika $P<0,05$ maka Ho ditolak

\section{HASIL DAN PEMBAHASAN}

1. Profil Perilaku Prososial Sebelum Penggunaan Alat Permainan Edukatif di Luar Kelas pada Anak Kelompok B Raudhatul Athfal Bandung (pretest)

Hasil penelitian menunjukkan bahwa perilaku prososial anak kelompok B di Raudhatul Athfal AlHikmah Bandung masih kurang karena perilaku prososial anak didominasi dengan kategori rendah sebanyak delapan anak atau mendominasi sebesar 53\% dan sangat rendah sebanyak tujuh anak atau sebesar $47 \%$.

Adapun rincian berdasarkan pada setiap aspek perilaku prososial, kemampuan anak berperilaku prososial ialah sebagai berikut: 


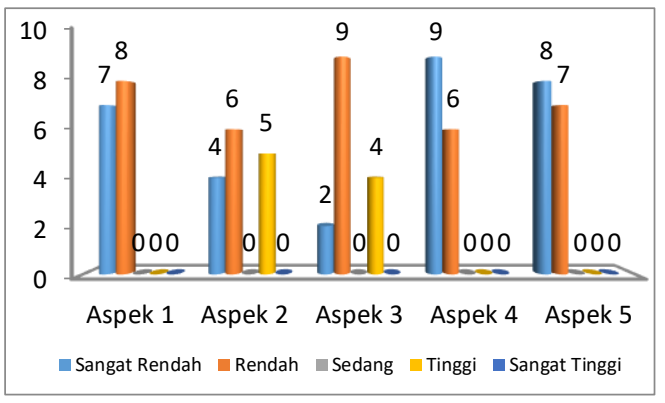

Gambar 4.1

Frekuensi Aspek Perilaku Prososial Sebelum Penggunaan Alat Permainan Edukatif di Luar Kelas

Jika diuraikan pada setiap aspek perilaku prososial, maka diketahui bahwa kondisi awal perilaku prososial anak sebelum penggunaan alat permainan edukatif di luar kelas yaitu aspek pertama (aspek empati) terdapat delapan anak pada kategori rendah dan tujuh anak pada kategori sangat rendah. Anak masih belum mampu menyapa teman-temannya dan anak masih bermain sendiri tanpa temantemannya.

Aspek kedua (aspek kedermawanan) pada kategori tinggi terapat lima anak, pada kategori rendah terdapat enam anak, dan pada kategori sangat rendah terdapat empat anak. Pada aspek kedua, terlihat anak sudah bisa mulai berbagi dengan teman-teman disekitarnya, namun masih banyak yang belum mampu berbagi dengan teman-temannya. Beberapa diantaranya terlihat berebut permainan.

Aspek ketiga (aspek kerja sama) pada kategori tinggi terdapat empat anak, pada kategori rendah terdapat sembilan anak, dan pada kategori sangat rendah terdapat dua anak. Pada aspek ini, terlihat anak belum dapat bermain secara bergiliran, dan belum dapat bermain dengan banyak teman lainnya. Namun pada aspek ini ada beberapa anak yang sudah mampu untuk menunggu giliran dan bermain bersama teman-teman mereka.
Aspek keempat (aspek perhatian) pada kategori rendah terdapat enam anak dan pada kategori sangat rendah terdapat sembilan anak. Pada aspek keempat, terlihat sembilan anak masih belum mampu menawarkan bantuan pada teman-temannya dan belum menunjukkan sikap menolong. Sementara itu, enam anak lainnya mampu menolong temannya ketika diminta pertolongan, namun masih belum mampu menawarkan bantuan pada teman-temannya.

Aspek kelima (aspek kepedulian) pada kategori rendah terdapat tujuh anak dan pada kategori sangat rendah terdapat delapan anak. Pada aspek kepedulaian terlihat anak masih belum mau untuk membantu temannya pada saat bermain. Anak juga masih belum mampu mengingatkan temannya untuk berhati-hati dan belum mampu menyemangati temannya.

Berdasarkan keseluruhan hasil data yang diperoleh, anak-anak masih berada pada kategori rendah dan sangat rendah. Pada profil awal perilaku prososial, diketahui bahwa YMN memiliki skor minimum yang paling rendah yaitu sejumlah 17 yang berada pada kategori sangat rendah.

Rendahnya tingkat kemampuan anak dalam berperilaku prososial pada tahap ini dikarenakan kurangnya penggunaan alat permainan edukatif di luar kelas yang menstimulasi anak untuk berinteraksi dengan teman sebayanya pada saat bermain. Padahal dari segi usia, anak kelompok B seharusnya sudah mampu menunjukkan perilaku prososial. Anak seharusnya sudah mampu saling menyapa, mengajak temannya bermain, saling menolong, berbagi, dan mampu bekerja sama dengan anak-anak lainnya. Adapun kriteria anak yang berperilaku prososial dalam Beaty (2013, hlm. 168) terlihat dari tingkah laku mereka, yaitu empati, kedermawanan, kerja sama, perhatian, 
dan kepedulian. Hal-hal tersebut merupakan beberapa ciri yang akan membantu anak untuk bergaul dalam masyarakat dan memotivasi orangorang untuk berinteraksi satu sama lain.

Perilaku prososial pada anak usia dini perlu diberikan perhatian khusus dan ditindaklanjuti pada tahapan penelitian selanjutnya. Hal ini dikarenakan perilaku prososial merupakan bagian dari aspek sosial yang tidak mampu dipisahkan dari seseorang terutama dari anak usia dini. Brower dan Casas (2015, hlm. 1) mengungkapkan bahwa selama beberapa tahun pertama, anak-anak mulai belajar keterampilan yang diperlukan untuk berinteraksi dengan orang lain dan membentuk hubungan yang kuat. Apabila perilaku prososial pada masa anak usia dini ini masih belum terstimulasi dengan baik, maka akan berdampak pada aspek perkembangan yang lainnya.

2. Profil Perilaku Prososial Sesudah Penggunaan Alat Permainan Edukatif di Luar Kelas pada Anak Kelompok B Raudhatul Athfal Bandung (posttest)

Berdasarkan hasil penelitian, diketahui bahwa perilaku prososial anak kelompok B di Raudhatul Athfal Al-Hikmah Bandung mengalami peningkatan. Perolehan penilaian dengan kategori sangat tinggi sebanyak delapan anak, pada kategori tinggi sebanyak lima anak, dan pada kategori sedang sebanyak dua anak. Dalam presentase, sebanyak 54\% anak memiliki perilaku prososial sangat tinggi, 33\% anak memiliki perilaku prososial yang tinggi, dan $13 \%$ anak memiliki kategori perilaku prososial yang sedang. Sementara itu, tidak ditemukan anak dengan kategori rendah dan sangat rendah pada perilaku prososial sesudah penggunaan alat permainan edukatif di luar kelas.
Adapun rincian berdasarkan setiap aspek perilaku prososial ialah sebagai berikut:

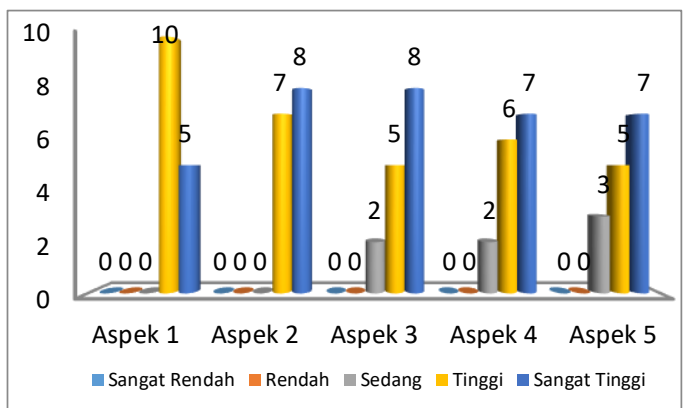

\section{Gambar 4.2}

Frekuensi Aspek Perilaku Prososial Sesudah Penggunaan Alat Permainan Edukatif di Luar Kelas

Jika diuraikan pada setiap aspek perkembangan perilaku prososial, diketahui bahwa kondisi perilaku prososial anak usia dini sesudah penggunaan alat permainan edukatif di luar kelas mengalami peningkatan khususnya pada bagian aspek-aspek prososial yaitu aspek pertama (aspek empati) pada kategori sangat tinggi lima anak, anak sudah mampu menhampiri temannya ketika diminta pertolongan, membantu temannya, mengajak temannya ntuk menolong teman lain yang sedang kesusahan juga mampu mengajak temnnya yang lain untuk bermain. Pada kategori tinggi sepuluh anak sudah menunjukkan perilaku menolong, menyapa teman-temannya, dan menghampiri ketika diminta pertolongan.

Aspek kedua (aspek kedermawanan) pada kategori sangat tinggi delapan anak dan pada kategori tinggi tujuh anak. Pada aspek kedua, terlihat anak sudah mampu berbagi dan tanpa berebut, sementara itu terlihat terdapat anak yang mampu mengengahi anak yang menginginkan alat permainan yang sama, anak mampu berbagi dan mengajak temannya untuk berbagi pada teman lainnya. 
Aspek ketiga (kerja sama) pada kategori sangat tinggi terdapat delapan anak, pada kategori tinggi terdapat lima anak, dan pada kategori sedang terdapat dua anak. Anak terlihat sudah mampu bermain dengan siapa saja, bermain secara bergiliran, mengingatkan temannya untuk menunggu giliran, dan mampu merangkul temannya yang mana saja untuk bermain bersama. Namun masih ditemukan anak yang perlu bantuan guru untuk mampu bermain bersama teman lainnya, dan masih perlu dibujuk untuk memainkan alat permainan secara bergiliran.

Aspek keempat (aspek perhatian) pada kategori sangat tinggi tujuh anak, pada kategori tinggi enam anak, dan pada kategori sedang terdapat dua anak. Pada aspek ini didominasi oleh anak yang sudah mampu saling tolong menolong tanpa meminta imbalan, mampu menawarkan bantuan, mampu mengingatkan temannya untuk memberikan bantuan tanpa mengungkit kembali (imbalan). Sementara itu, masih ditemukan anak yang mampu menawarkan bantuan hanya pada teman yang selalu bersamanya, tidak pada teman lainnya.

Aspek kelima (aspek kepedulian) pada kategori sangat tinggi tujuh anak, pada kategori tinggi lima orang anak, dan pada kategori sedang tiga anak. Terlihat anak sudah mampu menyemangati teman-temannya, anak juga sudah mampu mengingatkan teman-temannya. Namun masih terlihat beberapa anak yang masih perlu dibantu untuk terlebih dahulu menolong temannya yang lain dan menyemangati teman lainnya.

Berdasarkan keseluruhan penilaian sesudah penggunaan alat permainan edukatif di luar kelas, perilaku prososial anak mendapatkan banyak peningkatan. Terdapat satu orang anak yang memiliki kriteria perilaku prososial sangat tinggi, dengan perolehan skor akhir 64 yaitu DLL. Sementara itu, anak lainnya berada di bawah skor DLL, namun tetap masih pada kategori sangat tinggi dan tinggi, tidak terdapat anak yang termasuk kategori rendah atau sangat rendah sesudah penggunaan alat permainan edukatif di luar kelas.

Adanya peningkatan dalam berperilaku prososial pada anak, dikarenakan anak lebih menyukai penggunaan alat permainan edukatif di luar kelas. Penggunaan alat permainan edukatif di luar kelas memberikan kesempatan pada anak untuk belajar dan berkembang dari pengalaman yang mereka alami sendiri serta dilakukan dengan cara yang menyenangkan.

Untuk mengontrol perkembangan perilaku prososial anak, maka diperlukan penggunaan alat permainan edukatif di luar kelas pada saat anak melakukan kegiatan bermain.Pembberian tindakan (treatment) dengan penggunaan alat permainan edukatif diluar kelas dilakukan setiap hari sampai kondisi akhir (posttest). Hal ini dilakukan untuk mengendalikan ancaman luar yang masuk pada penelitian ini yang dapat mempengaruhi hasil penelitian agar tidak ada kebocoran kematangan, history, dan penggantian instrument yang mengubah hasil penelitian.

3. Pengaruh Penggunaan Alat Permainan Edukatif di Luar Kelas terhadap Perilaku Prososial Anak Usia Dini

Hasil penelitian menunjukkan bahwa terdapat peningkatan perilaku prososial anak sesudah penggunaan alat permainan edukatif di luar kelas. Sebanyak 54\% anak berada pada kategori sangat tinggi, 33\% pada kategori tinggi, dan $13 \%$ pada kategori sedang.

Selanjutnya, dilakukan uji normalitas data. Uji normalitas data pada penelitian ini menunjukkan 
bahwa data pada penelitian ini berdistribusi normal, karena nilai $\mathrm{P}>0,05$. Nilai pretest menunjukkan $0,200>0,05$ dan nilai posttest menunjukkan nilai 0,200>0,05 sehingga dapat diartikan bahwa data berdistribusi normal.

Setelah dilakukan uji normalitas data, selanjutnya dilakukan uji hipotesis untuk mengetahui pengaruh penggunaan alat permainan edukatif di luar kelas terhadap perilaku prososial anak. Uji hipotesis yang digunakan pada penelitian ini menggunakan uji Wilcoxon Matched Pairs Test dengan menggunakan bantuan software SPSS.

Berdasarkan perhitungan data hipotesis, didapatkan hasil uji Wilcoxon pada data pretest dan data posttest signifikan karena memiliki nilai $\mathrm{P}<0,05$. Hasil uji Wilcoxon didapatkan nilai $\mathrm{P}=0,001$, yang berarti $\mathrm{P}<0,05$.

Perolehan data dari uji Wilcoxon menunjukkan bahwa $\mathrm{H}_{\mathrm{o}}$ ditolak dan $\mathrm{H}_{\mathrm{a}}$ diterima, yang berarti terdapat peningkatan perilaku prososial yang signifikan pada anak dengan penggunaan alat permainan edukatif di luar kelas. Hal ini menunjukkan bahwa penggunaan alat permainan edukatif di luar kelas mempunyai pengaruh yang signifikan terhadap perilaku prososial anak usia dini di Raudhatul Athfal Al-Hikmah Bandung tahun ajaran 2017/2018.

\section{SIMPULAN}

\section{A. Kesimpulan}

Berdasarkan hasil penelitian dan pengujian hipotesis mengenai penggunaan alat permainan edukatif di luar kelas pada anak kelompok B di Raudhatul Athfal Bandung dapat disimpulkan sebagai berikut:

1. Perilaku prososial sebelum penggunaan alat permainan edukatif di luar kelas di Raudhatul Athfal Al-Hikmah Bandung menunjukkan hasil yang masih rendah dan sangat rendah. Perilaku prososial anak yang masih rendah diantaranya, anak belum mampu menolong temannya yang sedang kesusahan, masih banyak anak yang belum mampu bermain dengan teman yang mana saja, anak belum mampu memainkan permainan tanpa berebut, sebagian besar anak belum mampu bermain secara bergiliran, anak belum mapu menawarkan bantuan, serta anak belum mampu menyemangati teman-temannya.

2. Perilaku prososial sesudah penggunaan alat permainan edukatif di luar kelas diketahui bahwa kemampuan akhir perilaku prososial anak kelas B di Raudhatul Athfal Al-Hikmah Bandung meningkat secara signifikan dalam setiap aspek berperilaku prososial, terutama pada aspek perhatian dalam berperilaku prososial.

3. Berdasarkan hasil analisis data pretest dan posttest, dapat dikatakan bahwa penggunaan alat permainan edukatif di luar kelas dapat mempengaruhi peningkatan perilaku prososial anak secara signifikan. Hal ini dibuktikan melalui pengolahan data dengan menggunakan uji Wilcoxon Match Pairs Test yang diolah menggunakan bantuan SPSS. Hasil uji Wilcoxon Match Pairs Test pada penelitian ini diperoleh hasil HO ditolak dan Ha diterima. Sehingga dapat disimpulkan bahwa penggunaan alat permainan edukatif di luar kelas mempunyai pengaruh yang signifikan terhadap peningkatan perilaku prososial anak kelompok B di Raudhatul Athfal Al-Hikmah Bandung tahun ajaran 2017/2018. 


\section{B. Saran}

Berdasarkan hasil kajian teoritis serta hasil temuan penelitian, peneliti memberikan beberapa saran untuk guru maupun peneliti selanjutnya.

1. Bagi Guru

Hendaknya guru dapat memperhatikan kebutuhan bermain anak, dengan mengoptimalkan penggunaan alat permainan edukatif di luar kelas yang beragam dengan tetap memperhatikan keselamatan anak. Penggunaan alat permainan edukatif di luar kelas dapat dijadikan salah satu alternatif yang dapat dilakukan untuk menciptakan lingkungan sosial yang sesungguhnya bagi anak. Melalui alat permainan edukatif di luar kelas, anak dapat menciptakan dunia mereka bersama teman-teman mereka, anak mendapatkan suatu konflik sosial bersama teman-temannya, sehingga perilaku prososial anak akan berkembang dengan lebih optimal.

2. Bagi Peneliti Selanjutnya

Bagi peneliti selanjutnya disarankan untuk dapat mengembangkan penelitian mengenai perilaku prososial bagi anak usia dini, seperti perilaku empati, kedermawanan, kerja sama, perhatian, dan kepedulian. Peneliti selanjutnya dapat lebih memperdalam hasil penelitian ini sehingga mendapatkan hasil yang lebih baik dalam menghasilkan penelitan-penelitian selanjutnya.

Adapun bagi peneliti selanjutnya yang ingin mengembangkan penelitian mengenai alat permainan edukatif di luar kelas, dapat dikembangkan lebih mendalam karena alat permainan edukatif di luar kelas tidak hanya dapat berpengaruh pada peningkatan perilaku prososial, tetapi juga dapat menstimulasi banyak aspek perkembangan lainnya pada diri anak.

\section{DAFTAR PUSTAKA}

Abidin, Yunus. (2009). Bermain, Pengantar bagi Penerapan Pendekatan Beyond Centers and Circle Time (BCCT) dalam Dimensi PAUD. Bandung: RIZQI Press.

Beaty, Janice J. (2013). Observasi Perkembangan Anak Usia Dini. Jakarta: Kencana.

Bower, Alicia A, \& Casas, Juan F. (2015). What Parents Do When Children are Good: Parent Reports of Strategies for Reinforcing Early Childhood Prosocial Behaviors. Journal of Child and Family Studies, 25(4).

Eisenberg, Nancy \& Mussen, Paul H. (1989). The Roots of Prosocial Behavior In Children. Cambridge : Cambridge University Press 1989.

Limarga, Debora Meiliana. (2017). Penerapan Metode Bercerita dengan Media Audio Visual untuk Meningkatkan Kemampuan Empati Anak Usia Dini. Tunas Siliwangi. Universitas Pendidikan Indonesia Bandung, 3(1).

Mariyana, Rita., Ali Nugraha., \& Yeni Rachmawati. (2010). Pengelolaan Lingkungan Belajar. Jakarta: Kencana.

Mayfield, C.A., dkk. (2017). Effectiveness of a Playground Intervention for Antisocial, Prosocial, and Physical Activity Behaviors. Journal of School Health. American School Health Association, 87(5).

Sugiyono. (2011). Metode Penelitian Kombinasi (Mixed Methods). Bandung : IKAPI.

Sumartini, Tini. (2012). Bermain dan Jenis Permainan Anak Usia Dini. 
Bandung: PPPPTK TK dan PLB Bandung.

Supratiknya. (1993). Psikologi Kepribadian 1, Teori-teori Psikodinamik (Klinis). Yogyakarta: Kanisius.

Wildeboer, A. (2017). Nice traits or nasty states : dispositional and situational correlates of prosocial and antisocial behavior in childhood. (Tesis). Netherlands : Universiteit Leiden.

Woolley, H. \& Lowe, A. (2013) Exploring the relationship between play value and design approach of outdoor play spaces. Landscape Research, 38(1) . 